\title{
Mengukur Indeks Kebahagiaan Mahasiswa IPB Menggunakan Analisis Faktor
}

\author{
Aulya Permatasari*, Khairil Anwar Notodiputro*, Kusman Sadik* \\ *Departemen Statistika Institut Pertanian Bogor
}

\begin{abstract}
Abstrak-Mahasiswa program sarjana Institut Pertanian Bogor tersebar dalam 9 Fakultas dan 1 Sekolah. Perbedaan fakultas dan sekolah tersebut menggambarkan perbedaan karakteristik dan beban perkuliahan mahasiswa pada setiap fakultas dan sekolahnya. Perbedaan ini menimbulkan berbagai anggapan mengenai tingkat kebahagiaan mahasiswa pada setiap fakultas dan sekolah. Analisis tingkat kebahagiaan mahasiswa diukur menggunakan loading factor yang diperoleh dari hasil Analisis Faktor. Berdasakan hasil analisis tersebut, dijumpai Fakultas Peternakan merupakan fakultas paling bahagia dengan indeks kebahagiaan mencapai 66.88 dan indeks kebahagiaan terendah dijumpai pada Fakultas Ekologi Manusia dengan indeks kebahagiaan sebesar 62.39.

Kata kunci-biplot; kepuasan; loading factor; makna hidup; perasaan
\end{abstract}

\section{PENDAHULUAN}

\section{A. Latar Belakang}

Mahasiswa aktif Program Sarjana IPB tahun ajaran 2017/2018 terdiri atas 4 angkatan aktif, yakni angkatan 51, 52, dan 53 yang sudah tergabung dalam fakultas dan sekolah serta angkatan 54 yang masih tergabung dalam Program Pendidikan Kompetensi Umum (PPKU).

Masing-masing fakultas dan sekolah memiliki beban perkuliahan berbeda-beda. Fluktuasi tingkat kesulitan kegiatan perkuliahan yang diemban oleh mahasiswa pada setiap fakultas dan sekolah menimbulkan beragam pendapat mengenai tingkat kebahagiaan mahasiswa pada masing-masing fakultas dan sekolah tersebut. Hal ini kemudian mendorong rasa ingin tahu peneliti terhadap indeks kebahagiaan mahasiswa S1 IPB, khususnya mahasiswa aktif tahun ajaran 2017/2018 yang telah tergabung dalam fakultas dan sekolah.

Sebelumnya sudah ada penelitian serupa mengenai pengukuran tingkat kebahagiaan yang dilakukan oleh Badan Pusat Statistik (BPS) terhadap masyarakat Indonesia. Penelitian ini sudah dilakukan sebanyak 3 kali: tahun 2013, 2014, dan yang terbaru tahun 2017. Penelitian mengenai kebahagiaan warga dunia juga pernah dilakukan oleh Sustainable Development Solutions Network (SDSN) di bawah Perserikatan BangsaBangsa (PBB). Hasil dari penelitian PBB berupa The World Happiness Report yang terbit pada tahun 2012, 2013, 2015, 2016, dan laporan terbaru pada tahun 2017.

Data penelitian telah diperoleh melalui survei digital dengan penarikan contoh menggunakan metode Stratified Random Sampling. Selanjutnya, indeks kebahagiaan dihitung menggunakan bobot yang diperoleh dari hasil Analisis Faktor. Tujuan penting dari analisis faktor adalah untuk mencari faktorfaktor yang dapat menggambarkan hubungan antara variabel-variabel yang diobservasi (Rencher (2002)).

Selain menggunakan analisis faktor, hubungan antar peubah, objek, dan dimensi dapat dianalisa secara eksploratif menggunakan output Biplot. Biplot biasa digunakan untuk menyajikan data-data yang ada pada tabel ringkasan dalam grafik berdimensi dua. Analisis Biplot bersifat deskriptif berdimensi dua yang dapat menyajikan secara visual segugus objek dan variabel dalam satu grafik bidang datar (Mattjik AA (2011)). Dengan penyajian seperti ini, ciri-ciri variabel dan objek pengamatan serta posisi relatif antara objek pengamatan dengan variabel dapat dianalisis.

Berdasarkan uraian di atas dan untuk menjamin efektivitas dan efisiensi dari penelitian ini maka akan dijawab pertanyaan berikut:

1) Seberapa tinggi tingkat kebahagiaan mahasiswa IPB?

2) Seberapa tinggi tingkat kebahagiaan mahasiswa IPB menurut fakultas? 
3) Bagaimana kemiripan relatif objek menurut fakultasnya?

4) Bagaimana hubungan antar peubah?

5) Bagaimana keterkaitan antar indikator dengan dimensinya?

6) Bagaimana keterkaitan dimensi dengan fakultas?

\section{B. Tujuan}

Tujuan penelitian ini adalah mengetahui tingkat kebahagiaan mahasiswa S1 IPB tahun ajaran 2017/2018 melalui 14 peubah yang mewakili tiga dimensi: 1) Dimensi Kepuasan (Satisfaction), 2) Dimensi Perasaan (Affection), serta 3) Dimensi Makna Hidup (Eudaimonia). Selain itu ingin dilihat perbedaan tingkat kebahagiaan mahasiswa IPB serta kemiripan relatif antar objeknya. Hubungan antar peubah juga akan dilihat, serta posisi relatif objek dengan peubah-peubah yang tersedia.

\section{TINJAUAN PUSTAKA}

\section{A. Indeks Kebahagiaan}

The World Happiness Report adalah laporan hasil survei kebahagiaan warga dunia secara global yang diterbitkan oleh United Nations Sustainable Development Solutions Network (UN-SDSN). Laporan ini sudah diterbitkan 5 kali sejak penerbitan perdana tahun 2012.

Survei terakhir pada tahun 2017 melibatkan 3000 responden yang tersebar di 155 negara. Terdapat enam peubah kunci yang menunjukkan aspek kehidupan: 1) Pendapatan Domestik Bruto (PDB) perkapita, 2) Angka harapan hidup, 3) Dorongan sosial (diukur dengan intensitas seseorang terkena suatu masalah), 4) Kepercayaan (diukur dengan tingkat korupsi di pemerintahan dan dunia bisnis), 5) Kebebasan menentukan pilihan hidup, dan 6) Kemurahan hati (diukur dengan donasi terakhir) (Helliwell J (2017)).

Keberadaan The World Happiness Report menginspirasi BPS untuk membuat survei serupa, dinamai Survei Pengukuran Tingkat Kebahagiaan (SPTK). SPTK sudah dilaksanakan 3 kali pada tahun 2013, 2014, dan yang terbaru tahun 2017. Berdasarkan hasil SPTK terbaru, Indeks Kebahagiaan Indonesia tahun 2017 mencapai 70.69 pada skala 0 sampai 100.
Indeks kebahagiaan Indonesia tahun 2017 merupakan indeks komposit yang disusun dari tiga dimensi: 1) Dimensi Kepuasan Hidup (Life Satisfaction), 2) Dimensi Perasaan (Affection), serta 3) Dimensi Makna Hidup (Eudaimonia) (Hidayat Y (2016)). Nilai indeks pada masing-masing dimensi adalah sebagai berikut: (1) Indeks Dimensi Kepuasan Hidup sebesar 71.07; (2) Indeks Dimensi Perasaan sebesar 68.59; serta (3) Indeks Dimensi Makna Hidup sebesar 72.23. Seluruh indeks ini diukur pada skala 0 sampai 100 .

\section{B. Analisis Faktor}

Analisis faktor pertama kali diperkenalkan oleh Spearman pada 1904. Perhatian utama pada analisis faktor yaitu menemukan hubungan internal pada gugus peubah. Peubah-peubah dengan korelasi tinggi dimasukkan ke dalam suatu faktor sedangkan peubah-peubah dengan korelasi rendah dimasukkan ke dalam faktor berbeda. Ada dua jenis analisis faktor yaitu analisis faktor eksploratif dan konfirmatif (Johnson RA (2007)).

Vektor peubah acak $X$ yang terdiri atas $p$ indikator merupakan fungsi linear dari faktor umum $\left(F_{1}\right.$, $\left.F_{2}, \ldots, F_{m}\right)$ dan faktor khusus $\left(\epsilon_{1}, \epsilon_{2}, \ldots, \epsilon_{p}\right)$ yang dapat dituliskan dalam model sebagai berikut:

$$
\begin{array}{r}
X_{1}-\mu_{1}=l_{11} F_{1}+l_{12} F_{2}+\ldots+l_{1 m} F_{m}+\epsilon_{1} \\
X_{2}-\mu_{2}=l_{21} F_{1}+l_{22} F_{2}+\ldots+l_{2 m} F_{m}+\epsilon_{2} \\
\vdots \\
X_{p}-\mu_{p}=l_{p 1} F_{1}+l_{p 2} F_{2}+\ldots+l_{p m} F_{m}+\epsilon_{p}
\end{array}
$$

Atau dengan notasi matriks dinyatakan sebagai:

$$
\vec{X}-\vec{\mu}=L \vec{F}+\vec{\epsilon}
$$

Keterangan:

$X$ : vektor peubah berukuran $p \times 1$

$\mu$ : vektor rataan peubah berukuran $p \times 1$

$L$ : matriks $p \times m$ konstanta yang tidak diketahui nilainya (loading factor)

$F$ : vektor faktor umum berukuran $m \times 1$

$\epsilon$ : vektor $p \times 1$ unsur galat (faktor khusus)

(Raykov T (2008))

\section{METODOLOGI}

\section{A. Data}

Data yang digunakan pada penelitian ini adalah data primer, dikumpulkan melalui survei digital. Responden pada penelitian ini adalah mahasiswa aktif 
Institut Pertanian Bogor tahun ajaran 2017/2018 sebanyak 4 angkatan seperti yang tercantum dalam Tabel 1. Responden pada 4 angkatan tersebut tersebar dalam 9 fakultas dan 1 sekolah seperti yang disebutkan pada Tabel 2. Data diambil pada tanggal 4 Februari 2018 sampai tanggal 4 Maret 2018.

Tabel I

DAFTAR ANGKATAN DI IPB

\begin{tabular}{cc}
\hline Tahun masuk & Angkatan \\
\hline 2014 & 51 \\
2015 & 52 \\
2016 & 53 \\
2017 & 54 \\
\hline
\end{tabular}

Tabel II

DAFTAR FAKULTAS DAN SEKOLAH DI IPB

\begin{tabular}{cl}
\hline Abjad & \multicolumn{1}{c}{ Fakultas/Sekolah } \\
\hline A & Fakultas Pertanian \\
B & Fakultas Kedokteran Hewan \\
C & Fakultas Perikanan dan Ilmu Kelautan \\
D & Fakultas Peternakan \\
E & Fakultas Kehutanan \\
F & Fakultas Teknologi Pertanian \\
G & Fakultas Matematika dan Ilmu Penge- \\
& tahuan Alam \\
H & Fakultas Ekonomi dan Manajemen \\
I & Fakultas Ekologi Manusia \\
K & Sekolah Bisnis \\
\hline
\end{tabular}

Jumlah populasi target tercantum dalam Tabel 3 di bawah ini.

Kuesioner penelitian mengacu pada kuesioner Survei Pengukuran Tingkat Kebahagiaan 2017 yang dibuat oleh BPS, dengan penyesuaian terhadap karakteristik responden mahasiswa IPB. Struktur data dalam penelitian ini disajikan dalam Tabel 4 berikut.

\section{B. Model}

Model yang dihasilkan dari analisis ini berupa model analisis faktor yang diuraikan sebagai berikut

1) Model untuk mengetahui loading factor indikator penyusun Dimensi Kepuasan

$$
\underset{5 \times 1}{\mathrm{X}}-\underset{5 \times 1}{\mu}=\underset{5 \times 55 \times 1}{\mathrm{~L}} \underset{5 \times 1}{\mathrm{~F}}+\underset{5}{\epsilon}
$$

Keterangan:

$X$ : vektor indikator penyusun Dimensi
Tabel III

JUMLAH MAHASISWA IPB BERDASARKAN FAKULTAS

\begin{tabular}{|c|c|c|c|c|c|}
\hline \multirow{2}{*}{ Fakultas } & \multicolumn{4}{|c|}{ Angkatan } & \multirow[t]{2}{*}{ Total } \\
\hline & 51 & 52 & 53 & 54 & \\
\hline A & 416 & 398 & 439 & & 1691 \\
\hline B & 175 & 204 & 189 & & 793 \\
\hline $\mathrm{C}$ & 409 & 436 & 468 & & 1785 \\
\hline $\mathrm{D}$ & 191 & 199 & 234 & & 914 \\
\hline $\mathrm{E}$ & 367 & 367 & 367 & & 1483 \\
\hline $\mathrm{F}$ & 387 & 393 & 420 & & 1624 \\
\hline $\mathrm{G}$ & 626 & 642 & 677 & & 2690 \\
\hline $\mathrm{H}$ & 479 & 467 & 499 & & 1981 \\
\hline I & 326 & 292 & 315 & & 1271 \\
\hline $\mathrm{K}$ & & 82 & 96 & & 273 \\
\hline PPKU & & & & 3945 & 3945 \\
\hline Total & 3376 & 3480 & 3704 & 3945 & 14505 \\
\hline
\end{tabular}

Tabel IV

STRUKTUR DATA

\begin{tabular}{cclc}
\hline Dimensi & Kode & \multicolumn{1}{c}{ Peubah } & Tipe Data \\
\hline \multirow{4}{*}{ Kepuasan } & A1 & Pendidikan & Interval \\
& A2 & Pendapatan dan Pengeluaran & Interval \\
& A3 & Kesehatan & Interval \\
& A4 & Kehidupan Sosial & Interval \\
& A5 & Lingkungan dan Keamanan & Interval \\
\hline \multirow{4}{*}{ Perasaan } & B1 & Perasaan Riang Gembira & Interval \\
& B2 & Perasaan Khawatir & Interval \\
& B3 & Perasaan Tertekan & Interval \\
\hline \multirow{5}{*}{ Makna } & C1 & Kemampuan Menentukan & Interval \\
& C2 & Keputusan & \\
& Kemampuan Menciptakan & Interval \\
& C3 3 & Kondisi Nyaman & \\
& Konsistensi dalam Mengem- & Interval \\
& C4 & bangkan Potensi Diri & \\
& Kebermanfaatan Diri & Sikap Optimisme & Interval \\
& C6 & Sikap Lapang Dada & Interval \\
& & & \\
\hline
\end{tabular}

Kepuasan berukuran $5 \times 1$

$\mu$ : vektor rataan indikator penyusun Dimensi

Kepuasan berukuran $5 \times 1$

$L$ : matriks $5 \times 5$ loading factor yang digunakan

$F$ : vektor faktor umum berukuran $5 \times 1$

$\epsilon$ : vektor $5 \times 1$ unsur galat (faktor khusus)

2) Model untuk mengetahui loading factor indikator penyusun Dimensi Perasaan

$$
\underset{3 \times 1}{\mathrm{X}}-\underset{3 \times 1}{\mu}=\underset{3 \times 33 \times 1}{\mathrm{~L}} \underset{3 \times 1}{\mathrm{~F}}
$$


Keterangan:

$X$ : vektor indikator penyusun Dimensi Perasaan berukuran $3 \times 1$

$\mu$ : vektor rataan indikator penyusun Dimensi Perasaan berukuran $3 \times 1$

$L$ : matriks $3 \times 3$ loading factor yang digunakan

$F$ : vektor faktor umum berukuran $3 \times 1$

$\epsilon$ : vektor $3 \times 1$ unsur galat (faktor khusus)

3) Model untuk mengetahui loading factor indikator penyusun Dimensi Makna Hidup

$$
\underset{6 \times 1}{\mathrm{X}}-\underset{6 \times 1}{\mu}=\underset{6 \times 66 \times 1}{\mathrm{~L}}+\underset{6 \times 1}{\epsilon}
$$

Keterangan:

$X$ : vektor indikator penyusun Dimensi

Makna Hidup berukuran $6 \times 1$

$\mu$ : vektor rataan indikator penyusun Dimensi Makna Hidup berukuran $6 \times 1$

$L$ : matriks $6 \times 6$ loading factor yang digunakan

$F$ : vektor faktor umum berukuran $6 \times 1$

$\epsilon$ : vektor $6 \times 1$ unsur galat (faktor khusus)

4) Model untuk mengetahui loading factor dimensi penyusun Indeks Kebahagiaan

$$
\underset{3 \times 1}{\mathrm{I}}-\underset{3 \times 1}{\mu_{\mathrm{I}}}=\underset{3 \times 33 \times 1}{\mathrm{~L}_{\mathrm{I}}} \mathrm{F}_{\mathrm{I}}+\underset{3 \times 1}{\epsilon}
$$

Keterangan:

$I$ : vektor dimensi penyusun Indeks Kebahagiaan berukuran $3 \times 1$

$\mu_{I}$ : vektor rataan dimensi penyusun Indeks

Kebahagiaan berukuran $3 \times 1$

$L_{I}$ : matriks $3 \times 3$ loading factor yang digunakan

$F_{I}$ : vektor faktor umum berukuran $3 \times 1$

$\epsilon$ : vektor $3 \times 1$ unsur galat (faktor khusus)

\section{Prosedur Analisis Data}

Tahapan Analisis yang dilakukan dalam penelitian ini adalah sebagai berikut:

1) Eksplorasi data menggunakan statistika deskriptif untuk mengetahui gambaran umum keadaan mahasiswa Institut Pertanian Bogor.

2) Analisis faktor untuk menentukan pembobot pada setiap variabel. Bobot tersebut merupakan loading factor.

$$
\underset{p \times 1}{\mathrm{X}}-\underset{p \times 1}{\mu}=\underset{p \times p p \times 1}{\mathrm{~L}} \underset{p \times 1}{\mathrm{~F}}
$$

Keterangan:

$X$ : vektor peubah penelitian berukuran $p \times 1$

$\mu$ :vektor rataan peubah penelitian berukuran

$p \times 1$

$L$ : matriks $p \times m$ konstanta (loading factor)

$F$ : vektor faktor umum berukuran $m \times 1$

$\epsilon:$ vektor $p \times 1$ unsur galat (faktor khusus)

3) Menghitung indeks kebahagiaan mahasiswa IPB

Formula:

$$
\begin{gathered}
I_{\text {Kepuasan }}=\frac{\sum\left(w_{i} \times x_{i}\right)}{\sum w_{i}} \\
I_{\text {Perasaan }}=\frac{\sum\left(w_{i} \times x_{i}\right)}{\sum w_{i}} \\
I_{\text {MaknaHidup }}=\frac{\sum\left(w_{i} \times x_{i}\right)}{\sum w_{i}}
\end{gathered}
$$

Sehingga formula untuk mengukur indeks kebahagiaan:

$I=\frac{w_{1} \times I_{\text {Kepuasan }}+w_{2} \times I_{\text {Perasaan }}+w_{3} \times I_{\text {MaknaHidup }}}{w_{1}+w_{2}+w_{3}}$

Keterangan:

$w_{i}$ : bobot (yang diperoleh dari hasil perhitungan loading factor) $\mathrm{ke}-i$

$x_{i}$ : nilai peubah ke- $i$

(BPS (2017))

4) Menampilkan output biplot untuk melihat kemiripan relatif objek, hubungan antar peubah, serta melihat posisi relatif antara objek dan peubah

\section{HASIL DAN PEMBAHASAN}

\section{A. Karakteristik Responden}

Responden penelitian hasil survei berjumlah 407 responden yang tersebar di 4 angkatan, yakni angkatan 51, 52, 53, dan angkatan 54. Analisis indeks kebahagiaan mahasiswa IPB secara universal dilakukan melibatkan data seluruh mahasiswa tersebut, namun pada analisis indeks kebahagiaan tingkat fakultas dan sekolah hanya melibatkan data 300 mahasiswa angkatan 51, 52, dan 53. Mahasiswa angkatan 54 dianggap belum tergabung dalam fakultas dan sekolah karena masih mengikuti Program Pendidikan Kompetinsi Umum (PPKU). Sebaran 
Tabel V

SEBARAN RESPONDEN

\begin{tabular}{ccc}
\hline Abjad & Fakultas/Sekolah & Jumlah \\
\hline A & Faperta & 35 \\
B & FKH & 17 \\
C & FPIK & 36 \\
D & Fapet & 20 \\
E & Fahutan & 30 \\
F & Fateta & 36 \\
G & FMIPA & 54 \\
H & FEM & 40 \\
I & Fema & 26 \\
K & SB & 6 \\
\hline & Total & 300 \\
\hline
\end{tabular}

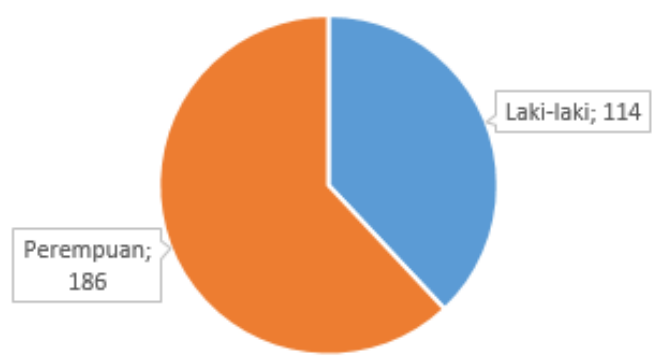

Gambar 1. Sebaran responden berdasarkan jenis kelamin

responden pada setiap fakultas dan sekolahnya tercantum dalam Tabel 5 di atas.

Dari 300 responden tersebut, 114 responden merupakan responden Laki-laki dan 186 lainnya merupakan responden Perempuan seperti yang tercantum pada Gambar 1 di atas.

\section{B. Indeks Kebahagiaan Mahasiswa IPB}

Indeks kebahagiaan Mahasiswa IPB dihitung menggunakan loading factor yang diperoleh dari hasil Analisis Faktor. Sebelum menentukan faktor yang akan digunakan, dapat dieksplor kemiripan karakteristik antar peubah dilihat dari matriks korelasinya. Nilai korelasi pada masing-masing peubah ditunjukkan pada tabel-tabel di bawah ini.

Tabel 6 menunjukkan korelasi antar indikator penyusun Dimensi Kepuasan. Berdasarkan hasil tabulasi tersebut, terlihat bahwa seluruh indikator memiliki korelasi positif antar satu dan lainnya, namun memiliki nilai yang relatif kecil. Diantara 5 indikator penyusun Dimensi Kepuasan tersebut, korelasi tertinggi terjadi antara peubah Pendidikan
Tabel VI

KORELASI ANTAR INDIKATOR PENYUSUN DIMENSI KEPUASAN

\begin{tabular}{cccccc}
\hline Indikator & $\mathrm{A} 1$ & $\mathrm{~A} 2$ & $\mathrm{~A} 3$ & $\mathrm{~A} 4$ & $\mathrm{~A} 5$ \\
\hline $\mathrm{A} 1$ & 1 & & & & \\
$\mathrm{~A} 2$ & 0.208 & 1 & & & \\
$\mathrm{~A} 3$ & 0.081 & 0.077 & 1 & & \\
$\mathrm{~A} 4$ & 0.174 & 0.138 & 0.194 & 1 & \\
$\mathrm{~A} 5$ & 0.052 & 0.038 & 0.062 & 0.029 & 1 \\
\hline
\end{tabular}

dengan peubah Pendapatan dan Pengeluaran sebesar 0.208 dan korelasi terendah terjadi antara peubah Kehidupan Sosial dengan peubah Lingkungan dan Keamanan yakni sebesar 0.029 .

Tabel VII

KORELASI ANTAR INDIKATOR PENYUSUN DIMENSI PERASAAN

\begin{tabular}{cccc}
\hline Indikator & B1 & B2 & B3 \\
\hline B1 & 1 & & \\
B2 & 0.143 & 1 & \\
B3 & 0.260 & 0.653 & 1 \\
\hline
\end{tabular}

Tabel 7 menunjukkan korelasi antar indikator penyusun Dimensi Perasaan. Berdasarkan hasil tabulasi tersebut, terlihat bahwa seluruh indikator juga memiliki korelasi positif satu sama lain. Diantara 3 indikator penyusun Dimensi Perasaan tersebut, korelasi cukup tinggi terjadi antara peubah Perasaan Khawatir dengan peubah Perasaan Tertekan yakni sebesar 0.653 sedangkan kombinasi lainnya memiliki korelasi rendah.

Tabel VIII

KORELASI ANTAR INDIKATOR PENYUSUN DIMENSI MAKNA HIDUP

\begin{tabular}{ccccccc}
\hline Indikator & $\mathrm{C} 1$ & $\mathrm{C} 2$ & $\mathrm{C} 3$ & $\mathrm{C} 4$ & $\mathrm{C} 5$ & $\mathrm{C} 6$ \\
\hline $\mathrm{C} 1$ & 1 & & & & & \\
$\mathrm{C} 2$ & 0.508 & 1 & & & & \\
$\mathrm{C} 3$ & 0.468 & 0.449 & 1 & & & \\
$\mathrm{C} 4$ & 0.448 & 0.463 & 0.632 & 1 & & \\
$\mathrm{C} 5$ & 0.475 & 0.412 & 0.534 & 0.535 & 1 & \\
$\mathrm{C} 6$ & 0.303 & 0.411 & 0.381 & 0.340 & 0.369 & 1 \\
\hline
\end{tabular}

Tabel 8 menunjukkan korelasi antar indikator penyusun Dimensi Makna Hidup. Berdasarkan hasil tabulasi tersebut, terlihat bahwa seluruh indikator juga memiliki korelasi positif satu sama lain, dengan nilai relatif cukup tinggi jika dibandingkan dengan korelasi pada dimensi lainnya. Diantara 6 
indikator penyusun Dimensi Makna Hidup tersebut, korelasi tertinggi terjadi antara peubah Konsistensi dalam Mengembangkan Potensi Diri dengan peubah Kebermanfaatan Diri yakni sebesar 0.632. Korelasi terendah terjadi antara peubah Kemampuan Menentukan Keputusan dengan peubah Sikap Lapang Dada yakni sebesar 0.303.

Nilai masing-masing dimensi penyusun Indeks Kebahagiaan juga dapat dieksplor korelasinya dalam Tabel 9 berikut ini.

Tabel IX

KORELASI ANTAR DIMENSI PENYUSUN INDEKS KEBAHAGIAAN

\begin{tabular}{cccc}
\hline Dimensi & Kepuasan & Perasaan & Makna Hidup \\
\hline Kepuasan & 1 & & \\
Perasaan & 0.344 & 1 & \\
Makna Hidup & 0.426 & 0.220 & 1 \\
\hline
\end{tabular}

Berdasarkan nilai korelasi pada Tabel 9 tersebut, terlihat bahwa antar dimensi memiliki korelasi yang tidak terlalu tinggi. Korelasi antara Dimensi Kepuasan dan Makna Hidup sebesar 0.426, korelasi antara Dimensi Kepuasan dan Perasaan sebesar 0.344, serta korelasi antara Dimensi Perasaan dan Makna Hidup hanya sebesar 0.220.

Analisis Faktor dilakukan sebanyak 4 kali. Analisis pertama terhadap indikator penyusun Dimensi Kepuasan, analisis kedua terhadap indikator penyusun Dimensi Perasaan, analisis ketiga terhadap indikator penyusun Dimensi Makna Hidup, serta analisis terakhir terhadap dimensi penyusun Indeks Kebahagiaan. Keseluruhan hasil analisis ini menghasilkan bobot untuk masing-masing peubah.

Bobot yang dipakai untuk setiap peubah menggunakan nilai eigen yang dimiliki pada setiap komponen dengan metode Komponen Utama. Pada setiap pemfaktoran yang dilakukan, diambil jumlah faktor maksimum dengan bobotnya merupakan proporsi nilai eigen terhadap total eigen tersebut. Berikut bobot untuk setiap peubah ditampilkan dalam Tabel 10 .

Berdasarkan hasil pembobotan tersebut, diperoleh indeks kebahagiaan mahasiswa IPB secara keseluruhan sebesar 64.88 yang tersusun atas tiga dimensi penyusunnya: Dimensi Kepuasan sebesar 62.78, Dimensi Perasaan sebesar 61.58, serta Dimensi Makna Hidup sebesar 73.33. Sedangkan pada
Tabel X

BOBOT SETIAP PEUBAH

\begin{tabular}{clc}
\hline Kode & \multicolumn{1}{c}{ Peubah } & Bobot \\
\hline A1 & Pendidikan & 0.1612 \\
A2 & Pendapatan dan Pengeluaran & 0.1994 \\
A3 & Kesehatan & 0.2916 \\
A4 & Kehidupan Sosial & 0.1532 \\
A5 & Lingkungan dan Keamanan & 0.1946 \\
\hline B1 & Perasaan Riang Gembira & 0.3013 \\
B2 & Perasaan Khawatir & 0.5867 \\
B3 & Perasaan Tertekan & 0.1120 \\
\hline C1 & Kemampuan Menentukan Keputusan & 0.1247 \\
C2 & Kemampuan Menciptakan Kondisi & 0.0877 \\
& Nyaman & \\
C3 & Konsistensi dalam Mengembangkan & 0.0600 \\
& Potensi Diri & \\
C4 & Kebermanfaatan Diri & 0.0738 \\
C5 & Sikap Optimisme & 0.1103 \\
C6 & Sikap Lapang Dada & 0.5435 \\
\hline & Kepuasan & 0.1820 \\
& Perasaan & 0.5557 \\
& Makna Hidup & 0.2623 \\
\hline
\end{tabular}

masing-masing fakultas dan sekolah diperoleh Indeks Kebahagiaan tertinggi pada mahasiswa Fakultas Peternakan sebesar 66.88 dan Indeks Kebahagiaan terendah pada mahasiswa Fakultas Ekologi Manusia sebesar 62.39.

Gambaran mengenai indeks kebahagiaan antar fakultas ditunjukkan oleh Gambar 2. Secara umum nilainya tidaklah jauh berbeda. Fakultas dengan indeks kebahagian diatas rata-rata indeks kebahagiaan mahasiswa IPB secara keseluruhan ialah Fapet dengan indeks kebahagiaan sebesar 66.88, FPIK sebesar 66.36, FEM sebesar 66.22, Faperta sebesar 65.45, serta FKH dengan indeks kebahagiaan sebesar 64.98. Sedangkan fakultas dengan indeks kebahagiaan di bawah rata-rata indeks kebahagiaan mahasiswa IPB secara umum ialah SB 64.21, Fateta 63.62, FMIPA 62.72, Fahutan 62.63, dan Fema dengan indeks kebahagiaan sebesar 62.39. Nilai indeks kebahagiaan mahasiswa IPB pada setiap fakultas dan sekolah beserta nilai tiga dimensi penyusunnya tercantum dalam Tabel 11.

Berdasarkan informasi pada Tabel 11 tersebut, dijumpai Indeks Kebahagiaan tingkat fakultas dan sekolah berada pada rentang 62.39 sampai 66.88 pada skala 0-100. Fakultas dengan indeks kepuasan terendah adalah Faperta sebesar 61.10 sedangkan 


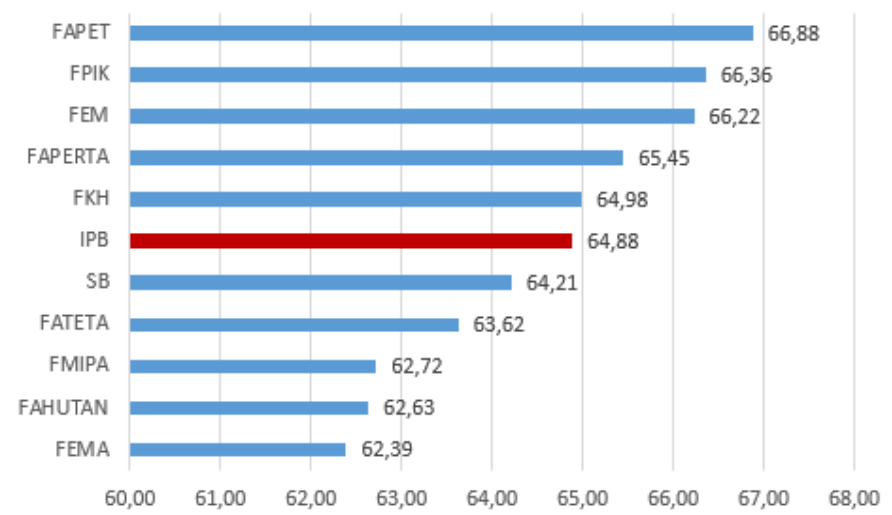

Gambar 2. Nilai indeks kebahagiaan berdasarkan fakultas dan sekolah

indeks kepuasan tertinggi dimiliki SB yakni sebesar 65.81. Fakultas dengan indeks perasaan tertinggi adalah Fapet yakni sebesar 66.22 dan indeks perasaan terendah dimiliki mahasiswa SB sebesar 56.55. Indeks makna hidup nilainya secara umum lebih tinggi daripada indeks kepuasan dan indeks perasaaan. Indeks makna hidup tertinggi dimiliki mahasiswa SB sebesar 79.33 tetapi indeks makna hidup terendah dimiliki mahasiswa FMIPA yakni sebesar 70.19 .

Tabel XI

INDEKS KEBAHAGIAAN BESERTA DIMENSI-DIMENSI PENYUSUNNYA PADA SETIAP FAKULTAS DAN SEKOLAH

\begin{tabular}{lllll}
\hline Fakultas & Kepuasan & Perasaan & Makna Hidup & Kebahagiaan \\
\hline Faperta & 61,10 & 62,85 & 73,97 & 65,45 \\
FKH & 64,85 & 60,47 & 74,64 & 64,98 \\
FPIK & 63,15 & 63,61 & 74,40 & 66,36 \\
Fapet & 63,41 & 66,22 & 70,66 & 66,88 \\
Fahutan & 62,54 & 58,38 & 71,70 & 62,63 \\
Fateta & 62,04 & 59,77 & 72,88 & 63,62 \\
FMIPA & 61,78 & 59,50 & 70,19 & 62,72 \\
FEM & 62,30 & 64,48 & 72,65 & 66,22 \\
Fema & 62,29 & 58,14 & 71,45 & 62,39 \\
SB & 65,81 & 56,55 & 79,33 & 64,21 \\
\hline
\end{tabular}

Hubungan antar peubah, objek, dan dimensi dapat dianalisa secara eksploratif menggunakan output Biplot. Gambar 3 menunjukkan gambar biplot dengan peubahnya berupa indikator penyusun Dimensi Kepuasan. Berdasarkan output tersebut, terlihat bahwa indikator Pendapatan dan Pengeluaran memiliki ragam paling minimum, sedangkan indikator dengan ragam tertinggi adalah indikator kesehatan. SB dominan dicirikan oleh indikator

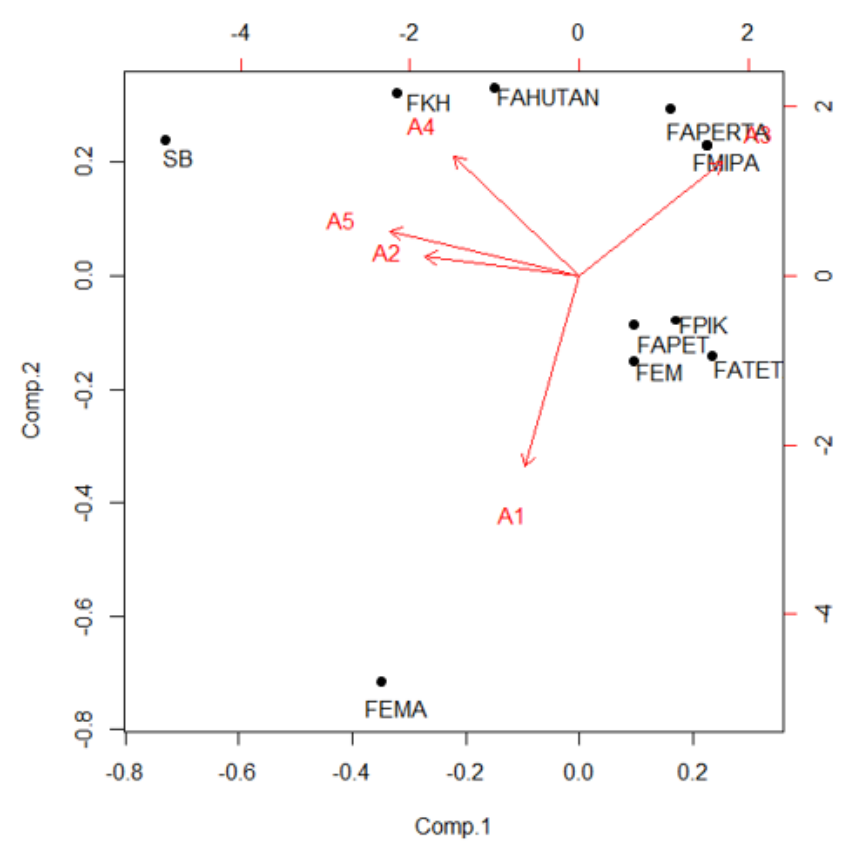

Gambar 3. Biplot Dimensi Kepuasan

Pendapatan dan Pengeluaran (A2) serta Lingkungan dan Keamanan (A5), sedangkan Faperta dan FMIPA dominan dicirikan oleh indikator Kesehatan (A3). FKH dan Fahutan dominan dicirikan oleh indikator Kehidupan Sosial (A4), serta Fema dominan dicirikan oleh indikator Pendidikan (A1). FPIK, Fapet, FEM, dan Fateta membentuk suatu gerombol tertentu, karena posisinya yang berdekatan, berlawanan arah dengan vektor-vektor indikator penyusun dimensi kepuasan lainnya.

Gambar 4 menunjukkan gambar biplot dengan peubahnya berupa indikator penyusun Dimensi Perasaan. Perasaan Khawatir (B2) dan Perasaan Tertekan (B3) memiliki keragaman data yang tidak terlalu berbeda, karena panjang vektor secara eksploratif dapat dikatakan hampir sama. Sedangkan keragaman pada vektor Perasaan Riang Gembira (B1) sedikit lebih panjang dari dua indikator lainnya. Fapet dominan dicirikan oleh Perasaan Khawatir, sedangkan fakultas lain menunjukkan posisi yang tidak terlalu dekat dengan indikator tertentu. FEM, Faperta, dan FPIK membentuk suatu gerombol kemiripan karakteristik pada dimensi perasaannya, sedangkan FKH, Fateta, FMIPA, dan FEMA membentuk gerombol yang lain. SB lebih dicirikan oleh Perasaan Riang Gembira, begitu pula 


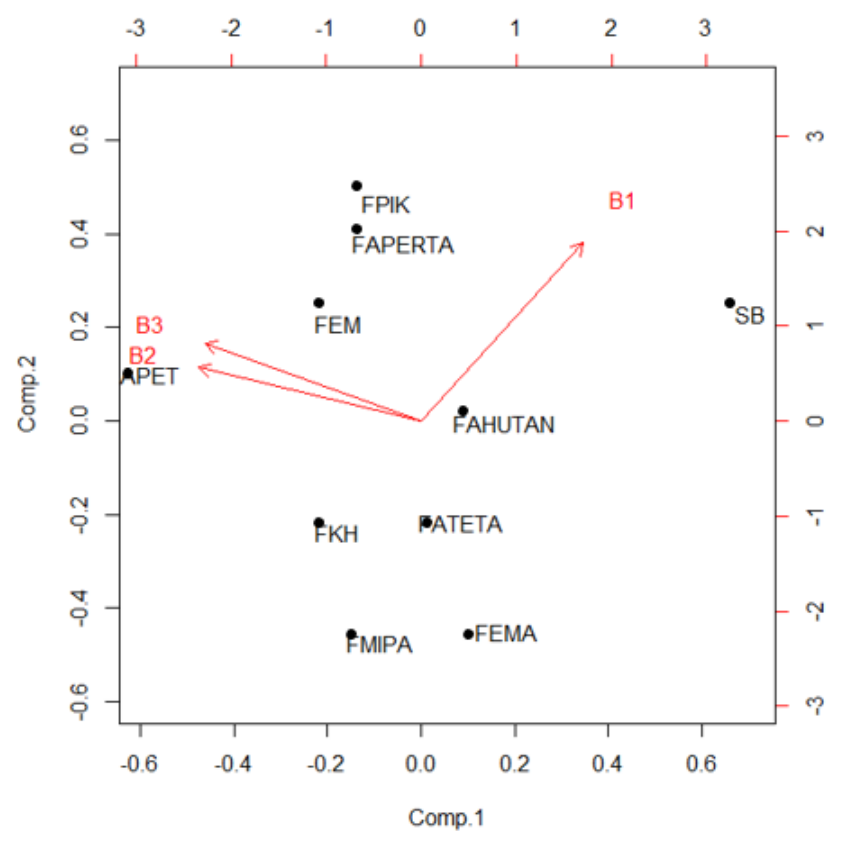

Gambar 4. Biplot Dimensi Perasaan

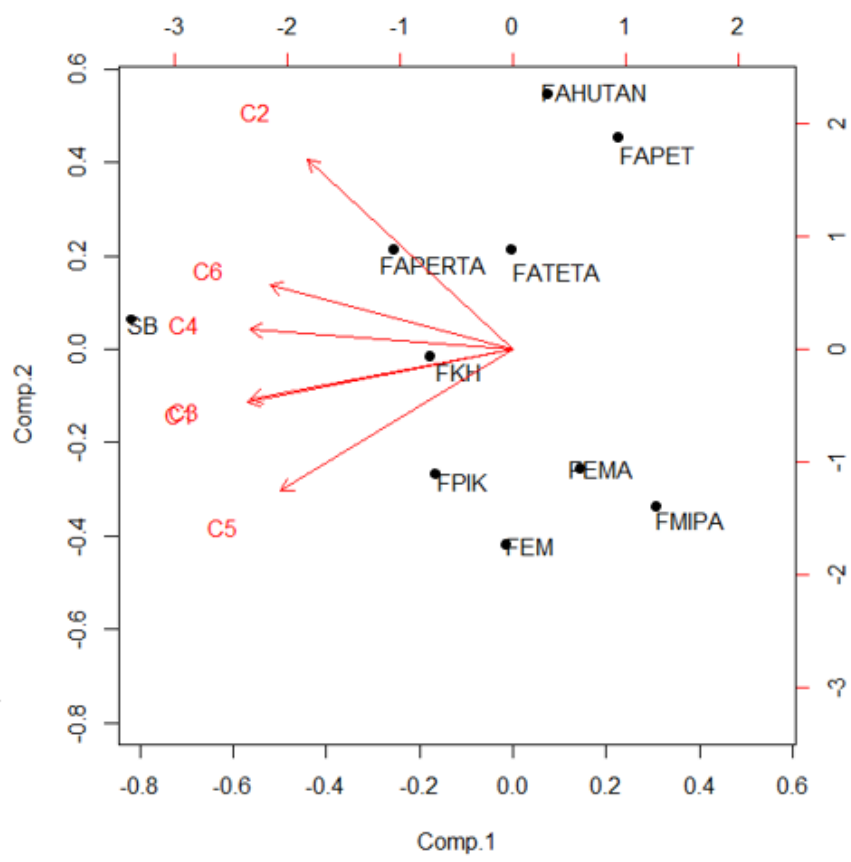

Gambar 5. Biplot Dimensi Makna Hidup

dengan Fahutan.

Keseluruhan indikator pada Dimensi Makna Hidup secara eksploratif terlihat memiliki keragaman yang tidak terlalu berbeda karena panjang vektor-vektornya yang relatif sama. SB dominan dicirikan oleh indikator Kebermanfaatan Diri (C4) sedangkan Faperta dan Fateta dominan dicirikan oleh indikator Kemampuan Menciptakan Kondisi Nyaman (C2). Fahutan dan Fapet memiliki karakteristik Makna Hidup yang relatif mirip karena posisinya yang berdekatan, serta FPIK, Fema, FEM, dan FMIPA membentuk satu gerombol lain.

\section{SIMPULAN}

Nilai Indeks Kebahagiaan dipengaruhi oleh tiga dimensi penyusunnya; Dimensi Kepuasan, Dimensi Perasaan, dan Dimensi Makna Hidup. Indeks perasaan masing-masing fakultas memiliki nilai yang paling rendah diantara indeks lainnya, namun memiliki bobot dimensi yang paling tinggi sehingga berpengaruh terhadap nilai Indeks Kebahagiaan. Indeks Kebahagiaan mahasiswa IPB secara keseluruhan sebesar 64.88 yang terdiri atas tiga dimensi penyusunnya: Dimensi Kepuasan sebesar 62.78, Dimensi Perasaan sebesar 61.58, serta Dimensi Makna Hidup sebesar 73.33. Indeks kebahagiaan tertinggi pada mahasiswa Fakultas Peternakan sebesar 66.88 dan Indeks Kebahagiaan terendah pada mahasiswa Fakultas Ekologi Manusia sebesar 62.39.

\section{DAFTAR PUSTAKA}

BPS (2017). Indeks kebahagiaan dki jakarta tahun 2017. BERITA RESMI STATISTIK, 1-11.

Helliwell J, Layard R, S. J. (2017). World Happiness Report 2017. New York: Sustainable Development Solutions Network.

Hidayat Y, Purwandari T, B. A. (2016). Mengukur indeks kebahagiaan kota bandung. Prosiding Seminar Nasional MIPA 2016, 1-11.

Johnson RA, W. D. (2007). Applied Multivariate Statistical Analysis. New Jersey: Prentice Hall.

Mattjik AA, S. I. (2011). Sidik Peubah Ganda dengan Mengggunakan SAS. Bogor: IPB Press.

Raykov T, M. G. (2008). An Introduction to Applied Multivariate Analysis. New York: Routledge.

Rencher, A. (2002). Methods of Multivariate Analysis. Canada: John Wiley and Sons, Inc. 